\title{
Dividend Policy as Moderating Variable to the Consumer Goods Company on the Indonesia Stock Exchange
}

\author{
Nagian Toni ${ }^{1 *}$, Enda Noviyanti Simorangkir ${ }^{2}$, Thomas Sumarsan Goh ${ }^{3}$ \\ ${ }^{1,2}$ Faculty of Economics, Universitas Prima Indonesia \\ Jln. Sekip Simpang Sikambing, Sumatera Utara 20118, Indonesia \\ ${ }^{3}$ Faculty of Economics, Universitas Methodist Indonesia \\ Jln. Hang Tuah No. 8, Sumatera Utara 20151, Indonesia \\ Inagiantoni@unprimdn.ac.id; ${ }^{2}$ endanoviyantisimorangkir@unprimdn.ac.id; ${ }^{3}$ Gohtho@gmail.com
}

Received: $19^{\text {th }}$ November 2020/ Revised: $1^{\text {st }}$ March 2021/ Accepted: $8^{\text {th }}$ July 2021

How to Cite: Toni, N., Simorangkir, E. N., \& Goh, T. S. (2021). Dividend Policy as Moderating Variable to the Consumer Goods Company on the Indonesia Stock Exchange. Binus Business Review, 12(3), 189-196.

https://doi.org/10.21512/bbr.v12i3.6815

\begin{abstract}
The capital market in Indonesia includes many companies from several sectors. One company that cannot be separated from the Indonesian stock market is a consumer goods company. The research aimed to analyze the effect of profitability and capital structure on the company with dividend policy as moderating variable to the consumer goods companies registered on the Indonesia Stock Exchange in the period of 2014-2018. The population in the research was consumer goods companies with subsector of food and drink, cigarette, cosmetic pharmacy, and household goods and appliances. The research applied purposive sampling and obtained 15 companies with 5 years of observation or around 75 samples. Then, the data were analyzed using Smart PLS 3.0. The analysis result shows that profitability, capital structure, and company size positively and significantly influence the company value. However, dividend policy cannot moderate the effect of profitability and capital structure on the company value. The dividend policy can moderate the effect of company size on the company value. Then, profitability, capital structure, and company size influence the company value of $88,6 \%$, while the other factors influence the rest. Investors should decide on issuers with high profitability above $5 \%$, the optimal capital structure with the debt-to-equity ratio between $0,8-1,2$, and total assets above five trillion Rupiah.
\end{abstract}

Keywords: dividend policy, consumer goods company, company profitability, capital structure

\section{INTRODUCTION}

The company value can be reflected in its market stock. The company value can bring the maximal prosperity of stockholders if the stock price of the company increases. The higher the stocks are, the higher the shareholder's wealth will be. The stocks in the capital market are taken based on the agreement between the demand and supply of investors. The capital market in Indonesia consists of many companies from several sectors. In implementing the operational activity, consumer goods companies cannot be separated from the Indonesian stock market. Stock as one of the investment instruments has the highest risks. Investors often search for investment options that offer a certain amount of risk with the highest return by taking into account the company value of an issuer. The company value shows the investor's perception regarding the company's success rate in managing resources, which is reflected in the company's share price at the end of the current year. A company's performance can be seen from the analysis of financial ratios to interpret the situation of a company's overall financial performance. It includes showing the cost of the corporation (Yundhari \& Sedana, 2020).

Company value can reflect the condition of the company. The better the company value is, the more prospective investors will see the company, and vice versa. Moreover, the shareholders' values will increase if the company value has a high return on investment (Sitanggang, Bukit, \& Erwin, 2019). Company value is the essential thing that the company 
must obtain to the maximum (Rahmantari, Sitiari, \& Dharmanegara, 2019). The maximum assessment of a company can be seen from its ability to survive so that it can be maintained properly (Rumajar, Hardi, \& Kurnia, 2018). Company value is also the investor's perception of the company's success rate, which is often associated with the stock price (Tondok, Pahlevi, \& Aswan, 2019). The company value can increase due to investors' assumptions on the company's internal factors. Company value is very important because the high company value will be followed by shareholders' high prosperity (Rosada \& Idayati, 2017). According to Husnan and Pudjiastuti (2015), the company value is the price that a prospective buyer is willing to pay if the company is sold. In the research, the company value is measured using Tobin's $Q$ equations. It is the indicator to assess the company performance, especially related to the company value, which shows the management performance in managing the active company.

The company value is very crucial for the company. It is important to explore all the possible factors that will improve the company value. The internal factors that can impact the company value are profitability, capital structure, company size, and company growth.

One of the ways to maximize company value lies in profitability. Profitability is the profit generated by the company as a result of business activities. A company must be clever in using company assets to generate profits, and it is called a profitability ratio (Ariyani, Pangestuti, \& Raharjo, 2018). If the company is considered profitable, the company will try to avoid selling shares and choose to get funds in other ways, including debt that exceeds the average capital structure (Nurfitriana \& Fachrurrozie, 2018). Profitability is also an indicator of management performance in managing the wealth of a company in the form of generated profits (Tho'in \& Prastiwi, 2019).

According to Sunyoto (2013), profitability is the company's ability to make a profit. High profitability is related to good company prospects, which stimulate investors to increase demand for stocks. As a result, higher profitability can lead to an increase in the company's stock price. The highest stock price has an impact on a higher company value. From the investor's perception, financial report analysis is one of the ways to predict the company's future. However, the review of financial statements will be useful from the point of view of management to help predict potential situations and, more importantly, the first point for the planning measures to enhance the company's success in the future. If management wants to maximize the company value, it needs to strengthen the company and fix its weakness (Paminto, Setyadi, \& Sinaga, 2016). The relationship between capital structure and profitability cannot be ignored because the improvement in profitability is necessary for the longterm survivability of the company (Khoiro, Suhadak, \& Handayani, 2016). The problem is the effectiveness of management in using total assets and net assets. The net profit assesses the effectiveness of the assets to produce a profit. According to Fahmi (2012), the equation of Return on Asset (ROA) is as follows.

$$
\mathrm{ROA}=\text { Profit after tax/Total assets }
$$

One of the decisions that must be faced by the manager of the company in relationship with the continuity of operations of the company is a capital structure decision. It can be said that the capital structure affects the company value. According to Rodoni and Ali (2014), capital structure is the proportion in determining the fulfillment of company spending needs. The fund is obtained using the combination or source guide from the long-term funds of outside and inside companies. Companies with a good business development level, in the long run, will provide large profits to investors (Purwanti, 2020). The capital structure has an important role in the company. The optimal or sub-optimal capital structure will have implications for the financial position of the company (Rusnindita, 2020). According to Kasmir (2014), the equation to count the debt-to-equity ratio is as follows.

$$
\mathrm{DER}=\text { Total debt/Equity }
$$

Then, in the management of the consumer goods company, the total assets owned by the company show the company size. The company size reflects the scale of assets owned by a company (Putu, Moeljadi, Djumahir, $\&$ Djazuli, 2014). The larger the company size is, the easier it is to get internal or external sources of funds, which can affect the company value. Large companies have been pushed to increase the company's economic growth due to enhanced company value. Companies with total assets have reached a stage of maturity. At this stage, the company's cash flow is positive and has good prospects (Gunawan, Pituringsih, \& Widyastuti, 2018). According to Hasnawati and Sawir (2015), an indicator of company size is the total assets, as shown in Equation (3).

$$
\text { Total Assets= Ln (Total assets) }
$$

Then, the dividend is the payment of a portion of profits from a company to shareholders. The dividend payments are one of the information awaited by shareholders. They perceive dividend payments as an indication of the company's financial health or a representative of its value (Surjandari, Anggraeni, Arlita, \& Purba, 2019). According to Halim (2015), stock price fluctuation is determined by the company's ability to make a profit. If profit obtained by the company is relatively high, the pay is also relatively high. If dividends of that pay are relatively high, it positively impacts the exchange price of stocks, and investors will want to buy it. It causes the request for stock to increase, and eventually, the price also increases.

Moreover, the dividend policy is the decision 
if the company's income will be paid as dividends to shareholders or held in the form of retained earnings to fund potential investment (Sartono, 2012). According to Sudana (2015), Dividend Payout Ratio (DPR) assesses how much the share of net income after tax is paid as dividends to shareholders. The ratio is the proportion of dividend to each share with the profit (Ifada, Faisal, Ghozali, \& Udin, 2019). The DPR is shown in Equation (4).

$$
\mathrm{DPR}=\text { Dividend/Earning after tax }
$$

The research aims to examine, test, and analyze the effect of profitability on company value, capital structure on company value, and company size on company value in consumer goods companies listed on the Indonesia Stock Exchange in the period of 20142018. Then, the research uses additional variables as moderation variables as a novelty of the research. The dividend policy is the moderating variable that is proxied by the consumer goods company. It is used as a moderating variable for the relationship between capital structures and profitability on the company value because it is an integral part of the company's financing decisions regarding its internal spending. Hence, the effect on the value of a company or the company's stock price can be seen. Dividend policy also becomes the center of attention of many parties as shareholders, creditors, or the other external party have the interests of the information released by the company. Thus, it implies that dividend policy can moderate the effect of profitability, capital structure, and company size on company value in consumer goods companies.

Based on the explanation, the research proposes several hypotheses as following:

H1: Profitability affects company value in consumer goods companies registered on Indonesia Stock Exchange in the period of 2014-2018.

$\mathrm{H} 2$ : Capital structure affects company value in consumer goods companies registered on Indonesia Stock Exchange in the period of 2014-2018.

H3: Company size affects company value in consumer goods companies registered on Indonesia Stock Exchange in the period of 2014-2018.

H4: Dividend policy moderates the effect of profitability on company value in consumer goods companies registered on Indonesia Stock Exchange in the period of 2014-2018.

H5: Dividend policy moderates the effect of capital structure on company value in consumer goods companies registered on Indonesia Stock Exchange in the period of 2014-2018.

H6: Dividend policy moderates the effect of company size on company value in consumer goods companies registered on Indonesia Stock Exchange in the period of 2014-2018.
The benefit of the research is to assist an investor to choose companies with high profitability, strong capital structure, and large company scale. Moreover, for the companies, they should consider conditions related to the efficiency of company value, increase the profit of the company, and maintain optimal or strong capital structure.

\section{METHODS}

The research applies a quantitative approach with the explanatory method as the research type. The data are financial statements from consumer goods companies listed on the Indonesia Stock Exchange in the period of 2014-2018. Those data are obtained from the website of the Indonesia Stock Exchange (www. idx.co.id).

The population in the research is 15 companies. The population is taken from food and beverage, cosmetics, household, and pharmacy as the subsector of consumer goods companies. The sample is collected using purposive sampling with simple random sampling or without considering systematic requirements. SmartPLS 3.0 is also used to analyze the sample. This tool is used since it is related to data normality that has no requirement for the total of the samples. Linear regression equation (see Equation (5)) can determine the relationship between dependent and independent variables.

$$
\mathrm{Y}=\mathrm{a}+\mathrm{b} 1 \mathrm{X} 1+\mathrm{b} 2 \mathrm{X} 2+\mathrm{bnXn}+\mathrm{e}
$$

Notes:

$\mathrm{Y}=$ Dependent variable

$\mathrm{X}=$ Independent variable

$\mathrm{a}=$ Constant

$\mathrm{b}=$ Coefficient of independent variable

$\mathrm{e}=$ Error

Moreover, the research implements inner model analysis to assess the significance for the path coefficient or t-value of each path between the studied variables. The value of the path coefficient or inner model shows the magnitude of the influence of exogenous latent variables on endogenous latent variables. The latent variable relationship arrow shows the standardized coefficient path value. If the standardized coefficient path value is bigger or equal to 0,1 , The effect of exogenous variables on endogenous variables is significant (the greater the value is, the greater the effect will be). It can also be assessed through the path coefficient score indicated by the $\mathrm{t}$-statistic value. The value must be bigger or equal to 1,96 for a two-way test (two-tailed) and 1,64 for oneway testing (one-tailed) to $\alpha=5 \%$ (Hair, Black, Babin, $\&$ Anderson, 2010). The end result from the structural model with significance model is implemented using the bootstrap method (non-parametric method). It causes PLS not to use the assumption since the data are normally distributed. So, the parameter significance test cannot be implemented (Hair, Ringle, Sarstedt, \& Hult, 2014). 


\section{RESULTS AND DISCUSSIONS}

Table 1 shows the minimum value, maximum value, mean value, and deviation standard from the profitability (X1), capital structure (X2), company size (X3), dividend policy (Z), and company value (Y).

Table 1 The Results of Descriptive Analysis

\begin{tabular}{ccccccc}
\hline Variable & N & Mean & Median & Min. & Max. & $\begin{array}{c}\text { Std. } \\
\text { Dev }\end{array}$ \\
\hline X1 & 75 & 0,150 & 0,104 & 0,029 & 0,527 & 0,120 \\
X2 & 75 & 0,842 & 0,621 & 0,074 & 3,029 & 0,644 \\
X3 & 75 & 29,691 & 29,637 & 26,543 & 32,201 & 1,457 \\
Y & 75 & 4,840 & 2,927 & 0,853 & 23,286 & 5,026 \\
Z & 75 & 0,506 & 0,430 & 0,084 & 1,535 & 0,305 \\
\hline
\end{tabular}

Profitability has the minimum value of 0,029 and the maximum value of 0,527 . Meanwhile, the mean value of 0,150 is with the deviation standard of 0,120 . Next, the capital structure shows the minimum value of 0,074 and the maximum value of 3,029 . Then, the mean value of 0,842 is with the deviation standard of 0,644 .

Company size has a minimum value of 26,54 and maximum value of 32,20. Meanwhile, the mean value of 29,691 is with the deviation standard of 1,457.
However, the company value has a minimum value of 0,853 and maximum value of 23,286 . Moreover, the mean value of 4,840 is with the deviation standard of 5,026. Next, dividend policy shows the minimum value of 0,084 and maximum value of 1,535. The mean value of 0,506 is with the deviation standard of 0,305 .

The loading factor describes how much the indicators are related to each construct. Figure 1 shows that all indicators have a loading factor value of 1,000 . It means that indicators are already valid because the loading factor value fulfills the criteria that the construct loading factor must be above 0,70 . The results show a good relationship between indicators with each construct.

The result from the Inner model of the R-squared test is shown in Table 2. It shows that profitability (X1), capital structure (X2), and company size (X3) can explain the company value (Y) around $88,6 \%$. Meanwhile, the remaining $(11,4 \%)$ is from other variables.

Table 2 Determination Coefficient

\begin{tabular}{ccc}
\hline & R-Squared & R-Squared Adjusted \\
\hline $\begin{array}{c}\text { Company } \\
\text { Value }\end{array}$ & 0,896 & 0,886 \\
\hline
\end{tabular}

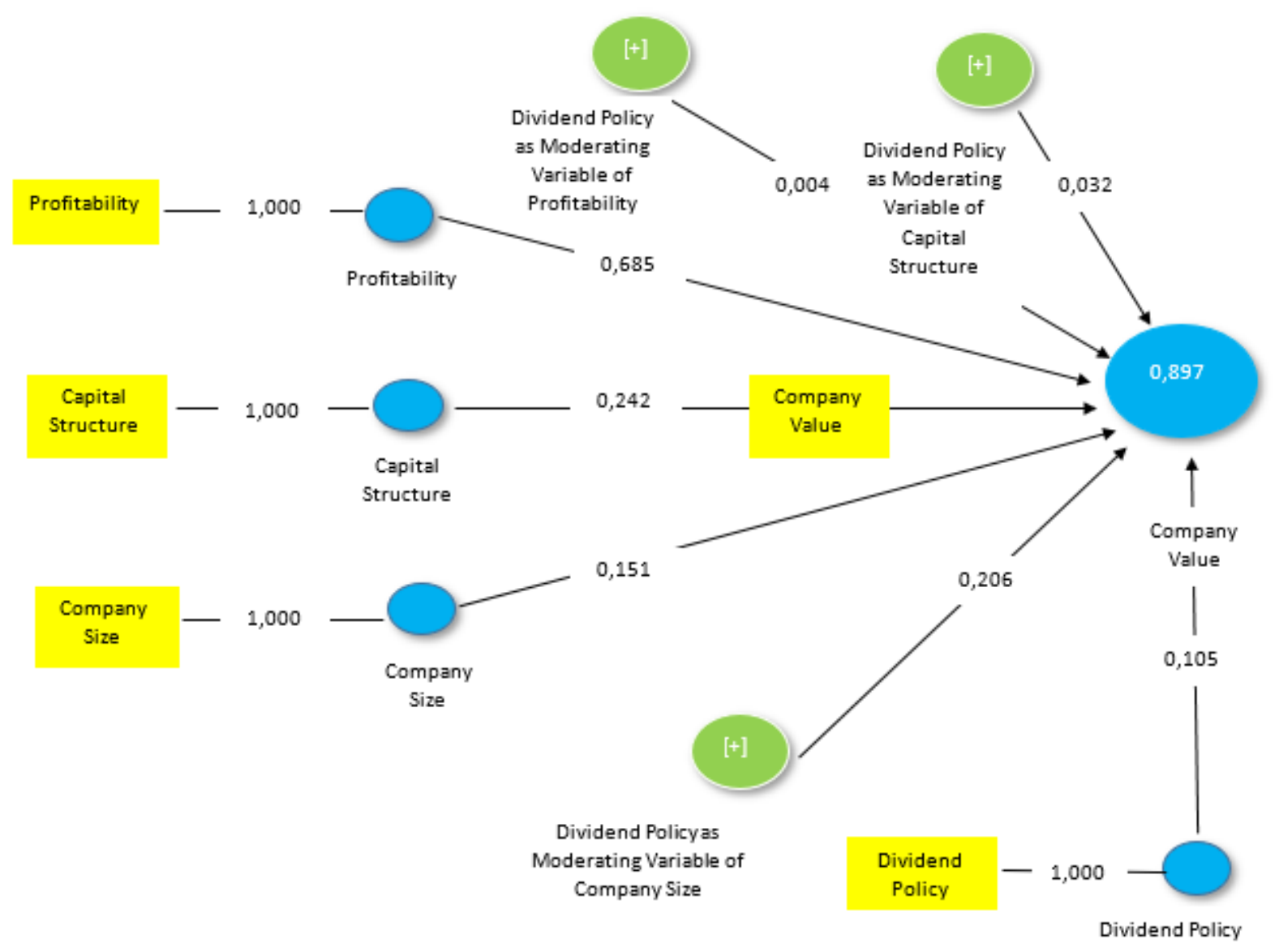

Figure 1 Model for PLS Algorithm Calculation 
Table 3 The Results of Hypothesis Test

\begin{tabular}{|c|c|c|c|c|c|}
\hline Hypotheses & $\begin{array}{c}\text { Original } \\
\text { Article } \\
\text { (O) }\end{array}$ & $\begin{array}{c}\text { Sample } \\
\text { Mean } \\
\text { (M) }\end{array}$ & $\begin{array}{l}\text { Standard } \\
\text { Deviation } \\
\text { (STDEV) }\end{array}$ & $\begin{array}{c}\text {-Statistic } \\
(|\mathrm{O} / \mathrm{STDEV}|)\end{array}$ & P-Values \\
\hline Company size on company value & 0,139 & 0,131 & 0,042 & 3,324 & 0,001 \\
\hline Profitability on company value & 0,733 & 0,715 & 0,137 & 5,359 & 0,000 \\
\hline $\begin{array}{l}\text { Dividend policy as moderating variable of } \\
\text { company size on company value }\end{array}$ & 0,207 & 0,191 & 0,073 & 2,842 & 0,005 \\
\hline $\begin{array}{l}\text { Dividend policy as moderating variable of } \\
\text { profitability on company value }\end{array}$ & $-0,055$ & $-0,024$ & 0,130 & 0,422 & 0,673 \\
\hline $\begin{array}{l}\text { Dividend policy as moderating variable of } \\
\text { capital structure on company value }\end{array}$ & 0,035 & 0,054 & 0,068 & 0,515 & 0,607 \\
\hline Dividend policy on company value & 0,100 & 0,082 & 0,083 & 1,209 & 0,227 \\
\hline Capital structure on company value & 0,269 & 0,236 & 0,092 & 2,940 & 0,003 \\
\hline
\end{tabular}

There are several results based on Table 3. First, the hypothesis test shows that the profitability effect on the company value has a path coefficient of 0,733 with a significance of $t$-statistics value of 5,359 (bigger than 1,96) and p-value of 0,000 (smaller than 0,05). It means that profitability has a positive and significant influence on the company value in consumer goods companies registered on Indonesia Stock Exchange in the period of 2014-2018. The results are confirmed by Chen and Chen (2011). There is a positive influence of profitability on company value. Profitability may affect the desire of the investors to invest. If the company has a high level of debt, it may cancel the positive effect of profitability on company value. The positive effect of profitability on company value means that high net income reflects the ability of the company to improve its profit. Therefore, it will improve the stock request and eventually the company value. High-profit rates always get a positive response from investors seen from the increase in the request of stock and improve the stock price in the capital market.

Second, the influence of capital structure on the company value has the path coefficient of 0,269 with a significance of t-statistics of 2,940 (bigger than 1,96) and p-value of 0,003 (smaller than 0,05 ). The results imply that capital structure has a positive and significant influence on the company value in consumer goods companies registered on Indonesia Stock Exchange in the period of 2014-2018. The results prove that the positive influence of capital structure on company value shows an increase of debt due to business development. For example, the availability of goods eventually can give the profit for the company. It has a positive impact on company performance because the effective use of debt will generate high profits and ultimately increase company value. According to
Ramdhonah, Solikin, and Sari (2019), capital structure positively influences company value. Moreover, good corporate governance, loan interest rates, and others can moderate the effect of capital structure on company value. Good corporate governance is a system that contains a set of regulations governing relationships among shareholders, management (managers) of the company, creditors, government, employees, and other internal and external stakeholders in relation to their rights and obligations. In other words, it is a system that regulates and controls a company to increase added value for all interested parties (stakeholders) (Mulyadi, Sihabudin, \& Sinaga, 2020).

Third, the hypothesis test shows that the influence of the company size on the company value has a path coefficient of 0,139 with a significance of t-statistics of 3,324 (bigger than 1,96) and p-value of 0,001 (smaller than 0,05 ). It means that company size has a positive and significant influence on the company value in consumer goods companies registered on Indonesia Stock Exchange in the period of 20142018. It shows that the larger the company size is, the higher the company value will be. As a result, large businesses tend to expand easily than small businesses. Creditors will have greater confidence in large companies. Hence, it will be easier to obtain debt for the company's expansion. The company that implements the trend of expansion will generate profit, and it will help to increase the company value. According to Rozi and Almurni (2020), profitability and liquidity significantly affect cash dividend policy. However, leverage does not affect the cash dividend policy. Then, company size strengthens the effect of profitability and liquidity on cash dividend policy and does not moderate the effect of leverage on cash dividend policy. 
Fourth, the effect of dividend policy as moderating variable of profitability on company value has the path coefficient of $-0,055$ with a significance of t-statistics of 0,422 (smaller than 1,96) and p-value of 0,673 (bigger than 0,05 ). It can be said that dividend policy cannot moderate the effect of profitability on the company value in consumer goods companies registered on Indonesia Stock Exchange in the period of 2014-2018. The analysis proves that dividend policy is unable to moderate the effect of profitability on company value. It is because the investors pay attention to not only dividend policy but also the company's fundamental factors. In this case, profitability shows the overall performance of the company. The increase in profit can enhance the company's profitability (Mufidah \& Sucipto, 2020). The company value is influenced by profitability that dividend policy cannot moderate the effect of profitability on company value. The profitability enhancement will increase the shared dividend so that the investors can give more value to the company (Ramdhonah et al., 2019). The results are in line with Mufidah and Sucipto (2020). The dividend policy weakens the leverage relation to the stock return. Otherwise, the dividend policy cannot moderate the profitability relationship and investment opportunity against the stock return.

Fifth, the influence of dividend policy as moderating variable of capital structure on the company value has a path coefficient of 0,035 with a significance of t-statistics of 0,515 (smaller than 1,96 ) and p-value of 0,607 (bigger than 0,05). It shows that the dividend policy is unable to moderate the effect of capital structure on the company value in consumer goods companies registered on Indonesia Stock Exchange in the period of 2014-2018. It indicates that capital structure is well-managed and increases the company's profitability and value. Therefore, if the capital gain is bigger, then the investors might expect a bigger capital gain than the dividend. The results are different from Irawati and Komariyah (2019) mentioning a positive influence of dividend policy on the capital structure. Moreover, based on Brigham and Houston (2010), dividend payments made by a company to shareholders may affect the company's external balance. If the internal funds are not adequate, the company will find another way to find the external funds, such as debts. However, the increase of debts can affect the sizeable net profit that is available to investors, including the accepted dividends (Kraft, Qu, Quatraro, \& Ravix, 2013).

Sixth, the hypothesis test shows that the influence of dividend policy as moderating variable of company size on company value has the path coefficient of 0,207 with a significance of t-statistics of 2,842 (bigger than 1,96) and p-value of 0,005 (smaller than 0,05 ). It means that dividend policy can moderate the effect of company size on the company value in consumer goods companies registered on Indonesia Stock Exchange in the period of 2014-2018. According to Apriliyanti, Hermi, and Herawaty (2019), investors tend to choose a company that pays dividends rather than capital gain because of its certainty. Hence, the dividend increase will also increase the company value. The results are also supported by Rahmawati, Darmawan, Setyarini, and Bagis (2021). Company performance or value will be considered good and profitable if the dividend distribution to stakeholders is higher. Therefore, it can be seen that the dividend distribution has a positive impact on company size toward the company value. Investors will appreciate the highest stock number for the companies with higher rates and payment of dividends.

\section{CONCLUSIONS}

Based on the results of data analysis, the main finding is that profitability, capital structure, and company size has a positive and significant influence on the company value in consumer goods companies registered on Indonesia Stock Exchange in the period of 2014-2018. The dividend policy also moderates the effect of company size on the company value. However, the dividend policy cannot moderate the effect of profitability and capital structure on company value. Hence, it can be concluded that the company value is affected by profitability, capital structure, and company size. Then, the dividend policy is only able to moderate the effect of company size against the company value.

The implication of the research is expected to help investors to choose companies with high profitability, strong capital structure, large company size, total assets of five trillion Rupiah or more, and regular payment of dividends every year. Moreover, the companies need to focus on profitability by observing cost efficiency, increasing company turnover, and maintaining capital structure.

There is a limitation in the research. The research analyses consumer goods company listed on Indonesia Stock Exchange from 2014 to 2018. It is also limited to the profitability, company structure, and dividend policy. Therefore, for further research, it is suggested to analyze other company sectors, such as real estate company, property company, manufacture, and market company listed on the Indonesia Stock Exchange. Moreover, future research can analyze other factors that still affect the company value. For example, the indicators include asset productivity, liquidity, implementation of good corporate governance, and others.

\section{REFERENCES}

Apriliyanti, V., Hermi, H., \& Herawaty, V. (2019). Pengaruh kebijakan hutang, kebijakan dividen, profitabilitas, pertumbuhan penjualan dan kesempatan investasi terhadap nilai perusahaan dengan ukuran perusahaan sebagai variabel moderasi. Jurnal Magister Akuntansi Trisakti, 6(2), 201-224. https://doi. org/10.25105/jmat.v6i2.5558

Ariyani, H. F., Pangestuti, I. R. D., \& Raharjo, S. T. (2018). 
The effect of asset structure, profitability, company size, and company growth on capital structure (The study of manufacturing companies listed on the IDX for the period 2013 - 2017). Jurnal Bisnis Strategi, 27(2), 123-136. https://doi.org/10.14710/ jbs.27.2.123-136

Brigham, E. F., \& Houston, J. F. (2010). Essentials of financial management. Cengage Learning.

Chen, L. J., \& Chen, S. Y. (2011). The influence of profitability on firm value with capital structure as the mediator and firm size and industry as moderators. Investment Management and Financial Innovations, $8(3), 121-129$.

Fahmi, I. (2012). Pengantar manajemen keuangan: Teori dan soal jawab. Alfabeta.

Gunawan, I. M. A., Pituringsih, E., \& Widyastuti, E. (2018). The effect of capital structure, dividend policy, company size, profitability and liquidity on company value (Study at manufacturing companies listed on Indonesia Stock Exchange 2014-2016). International Journal of Economics, Commerce and Management, 4(6), 405-422.

Hair, J. F., Black, W. C., Babin, B. J., \& Anderson, R. E. (2010). Multivariate data analysis. Prentice Hall.

Hair, J. F., Ringle, C., Sarstedt, M., \& Hult, G. T. M. (2014). A primer on Partial Least Squares Structural Equation Modeling (PLS-SEM). SAGE Publications.

Halim, A. (2015). Analisis investasi di aset keuangan. Mitra Wacana Media.

Hasnawati, S., \& Sawir, A. (2015). Keputusan keuangan, ukuran perusahaan, struktur kepemilikan dan nilai perusahaan publik di Indonesia. Jurnal Manajemen dan Kewirausahaan (Journal of Management and Entrepreneurship), 17(1), 65-75. https://doi. org/10.9744/jmk.17.1.65-75

Husnan, S., \& Pudjiastuti, E. (2015). Dasar-dasar manajemen keuangan. UPP STIM YKPN.

Ifada, L. M., Faisal, F., Ghozali, I., \& Udin, U. (2019). Company attributes and firm value. Evidence from companies listed on Jakarta Islamic Index. Revista Espacios, 40(37), 11.

Irawati, A. E., \& Komariyah, E. F. (2019). The role of capital structure on the effect of dividend policy and business risk on firm value (Evidence from Indonesian manufacturing company). The Indonesian Journal of Accounting Research, 22(2), 207-228.

Kasmir. (2014). Analisis laporan keuangan. PT. Raja Grafindo Persada.

Khoiro, E. E. U., Suhadak, \& Handayani, S. R. (2016). The influence of capital structure and firm size on profitability and dividend policy (An empirical study at property and real estate sector listed in Indonesia Stock Exchange during the periods of 2009-2012). PROFIT: Jurnal Administrasi Bisnis, 10(2), 1-10. https://doi.org/10.21776/ub.profit.2016.010.02.1

Kraft, J., Qu, Y., Quatraro, F., \& Ravix, J. L. (2013). Corporate governance, value and performance of firms. University of Nice Sophia Antipolis.

Mufidah, N., \& Sucipto, A. (2020). The moderating role of dividend policy on the influence of liquidity, profitability, leverage, and investment opportunity set against stock return registered in the Jakarta Islamic Index. Media Ekonomi dan Manajemen, 35(2), 188-205. https://doi.org/10.24856/mem. v35i2.1553

Mulyadi, D., Sihabudin, \& Sinaga, O. (2020). Analysis of current ratio, net profit margin, and good corporate governance against company value. Systematic Reviews in Pharmacy, 11(1), 588-600.

Nurfitriana, A., \& Fachrurrozie. (2018). Profitability in moderating the effects of business risk, company growth and company size on debt policy. JASF (Journal of Accounting and Strategic Finance), 1(2), 133-142. https://doi.org/10.33005/jasf.v1i02.18

Paminto, A., Setyadi, D., \& Sinaga, J. (2016). The effect of capital structure, firm growth and dividend policy on profitability and firm value of the oil palm plantation companies in Indonesia. European Journal of Business and Management, 8(33), 123-134.

Purwanti, T. (2020). The effect of profitability, capital structure, company size, and dividend policy on company value on the indonesia stock exchange. International Journal of Seocology, 1(02), 060-066. https://doi.org/10.29040/seocology.v1i02.9

Putu, N. N. G. M., Moeljadi, Djumahir, \& Djazuli, A. (2014). Factors affecting firms value of Indonesia public manufacturing firms. International Journal of Business and Management Invention, 3(2), 35-44.

Rahmantari, N. L. L., Sitiari, N. W., \& Dharmanegara, I. B. A. (2019). Effect of corporate social responsibility on company value with company size and profitability as moderated variables in pharmaceutical companies listed on the Indonesia Stock Exchange. Jurnal Ekonomi \& Bisnis JAGADITHA, 6(2), 121-129.

Rahmawati, D. V., Darmawan, A., Setyarini, F., \& Bagis, F. (2021). Profitability, capital structure and dividend policy effect on firm value using company size as a moderating variable (In the consumer goods industry sector companies listed on the Indonesia Stock Exchange (IDX) during 2015-2019 periods). International Journal of Economics, Business and Accounting Research (IJEBAR), 5(1), 282-292.

Ramdhonah, Z., Solikin, I., \& Sari, M. (2019). Pengaruh struktur modal, ukuran perusahaan, pertumbuhan perusahaan, dan profitabilitas terhadap nilai perusahaan (Studi empiris pada perusahaan sektor pertambangan yang terdaftar di Bursa Efek Indonesia tahun 2011-2017). Jurnal Riset Akuntansi dan Keuangan, 7(1), 67-82.

Rodoni, A., \& Ali, H. (2014). Manajemen keuangan modern. Mitra Wacana Media.

Rosada, F. L. A., \& Idayati, F. (2017). Pengaruh profitabilitas terhadap nilai perusahaan otomotif di Bursa Efek Indonesia. Jurnal Ilmu dan Riset Akuntansi (JIRA), 6(1), 255-274.

Rozi, F., \& Almurni, S. (2020). Pengaruh profitabilitas, likuiditas, dan leverage terhadap kebijakan dividen kas dengan ukuran perusahaan sebagai variabel moderasi (Studi empiris perusahaan consumer goods yang terdaftar di Bursa Efek Indonesia tahun 2016-2018) (Unpublished). Sekolah Tinggi Ilmu Ekonomi Indonesia. 
Rumajar, D. U. N., Hardi, \& Kurnia, P. (2018). Pengaruh pengungkapan Corporate Social Responsibility (CSR) terhadap nilai perusahaan dengan ukuran perusahaan sebagai variabel moderasi (Studi empiris pada perusahaan perkebunan yang terdaftar di BEI periode 2015- 2016). Jurnal Online Mahasiswa Fakultas Ekonomi, 1(1), 1-15.

Rusnindita, K. R. (2020). Analysis of size, ROA, and growth of corporate value; With variable capital structure as intervening. International Journal of Science, Engineering, and Information Technology, 4(2), 203-208. https://doi.org/10.21107/ijseit.v4i2.6242

Sartono, A. (2012). Manajemen keuangan teori dan aplikasi. BPFE.

Sitanggang, T. N., Bukit, R., \& Erwin, K. (2019). Factors that influence company value with capital structure as a moderating variable in manufacturing companies listed in Indonesia Stock Exchange (IDX). International Journal of Public Budgeting, Accounting and Finance, 2(1), 1-11.

Sudana, I. M. (2015). Manajemen keuangan perusahaan: Teori dan praktik. Erlangga.

Sunyoto, D. (2013). Metodologi penelitian akuntansi. PT Refika Aditama.
Surjandari, D. A., Anggraeni, D., Arlita, D. P., \& Purba, R. M. (2019). Analysis of non-financial determinants of company value in manufacturing companies in Indonesia. Jurnal Akuntansi, 23(2), 230-252. http:// dx.doi.org/10.24912/ja.v23i2.584

Tho'in, M., \& Prastiwi, I. E. (2019). An analysis the Rupiah exchange rates effect against the American Dollar and inflation against the growth of Islamic Banking Mudharabah Deposits in Indonesia. International Journal of Islamic Business and Economics (IJIBEC), 3(1), 82-91. https://doi.org/10.28918/ ijibec.v3i1.1797

Tondok, B. S., Pahlevi, C., \& Aswan, A. (2019). Pengaruh struktur modal, pertumbuhan perusahaan, ukuran perusahaan terhadap profitabilitas dan nilai perusahan pada perusahaan manufaktur yang terdaftar di Bursa Efek Indonesia periode 2013-2017. Hasanuddin Journal of Business Strategy, 1(3), 66-78.

Yundhari, N. W. T., \& Sedana, I. B. P. (2020). The effect of profitability, growth, and asset structure on company value with capital structure as mediation on consumer goods companies in Indonesia Stock Exchange. International Journal of Business Marketing and Management (IJBMM), 5(1), 21-33. 